\title{
Reading Gerry Kearns' Geopolitics and Empire: The Legacy of Halford Mackinder
}

\author{
Geopolitics and Empire: the Legacy of Halford Mackinder, Gerry Kearns. Oxford University Press, New York (2009). xiv + 344 pp.; \\ bibliog., index. US \$100.00 (cloth), ISBN: 9780199230112
}

\author{
John Agnew ${ }^{\text {a }}$, Matthew G. Hannah ${ }^{\text {b }}$, Joanne Sharp ${ }^{\text {, }}$ Peter J. Hugill ${ }^{\text {d }}$, Lorraine Dowler ${ }^{\text {e, }}$, Gerry Kearns ${ }^{\mathrm{f}}$ \\ a Department of Geography, UCLA, 1225 Bunche Hall, Los Angeles, CA 90095, United States \\ ${ }^{\mathrm{b}}$ Institute of Geography and Earth Sciences, Aberystwyth University, Llandinam Building, Penglais, Aberystwyth SY23 3DB, United Kingdom \\ ${ }^{c}$ Department of Geographical and Earth Sciences, University of Glasgow, Glasgow G12 8QQ United Kingdom \\ d Department of Geography and Bush School International Affairs Program, Texas AEM University, College Station, TX 77843, United States \\ e Departments of Geography and Women's Studies, Penn State University, 324 Walker Building, University Park, PA 16802, United States \\ ${ }^{\mathrm{f}}$ School of Public and International Affairs, Virginia Tech, 112 Architecture Annex (0113), Blacksburg, VA 24061, United States
}

\section{Introduction}

\section{John Agnew}

Halford Mackinder has had a posthumous existence that many of us might envy. Long after his earthly demise, some of his ideas, particularly that of the "geographical pivot of history," keep coming back to life. Currently, some well-known pundits in US foreignpolicy circles, typically thought of as neo-conservative and keen on a "muscular" US military presence around the world, have re-discovered Mackinder's geographical determinism as providing a seemingly naturalistic account for the approaching rebirth of the "yellow peril" (the rise of China) and offering as it did at the turn of the last century a timeless rendering of the challenges to the democratic maritime powers from the despotic land powers of Eurasia. The widely cited American journalist Robert Kaplan (2010: 22), for example, frames the emerging "geography" of China's power almost entirely in these terms. It is timely, therefore, to have a new intellectual biography of Mackinder that not only critically engages with the central themes of his geopolitics but that does so by both situating them in the historical context of the early twentieth century and showing why they remain attractive in some quarters by dint of their effective depoliticization of the very world politics that they underwrite. This book matters, therefore, in a number of distinctive ways. That was why a session devoted to it was so worth organizing at the Washington DC AAG Annual Meeting in April 2010.

When I first heard from Gerry Kearns that he was planning to write a book focused on Mackinder and his geopolitics I must admit to having been less than enthusiastic. I have spent some time and energy down the years trying to expropriate the word "geopolitics"

\footnotetext{
* Corresponding author.

E-mail address: lxd17@psu.edu (L. Dowler).
}

for uses other than those ascribed to Mackinder and his ilk of early twentieth century imperialists. But I erred. Gerry has done much more than write a conventional biography of Mackinder. A very serviceable one by Brian Blouet (1987) already exists. The various commentaries that follow this Introduction outline what the book does across the course of its nine chapters. More critically they also show how the book contributes to our understanding of both why it was Mackinder's ideas and not those of some contemporaries that tended to win out and why these ideas have had a continuing resonance, particularly in policy-making circles in certain foreign ministries, years after the immediate historical context in which Mackinder lived has long disappeared. What is important to emphasize above all as its leitmotif is that this book is illustrative of a successful use of the biography of a singularly influential geopolitical thinker to show how alternative geopolitical scenarios and futures have always been and still are possible.

Mackinder never used the word geopolitics. Yet, at least in the English-speaking world, it is to him and a couple of other writers from around his lifetime (Mahan, for example) that the term is frequently ascribed. In lodging the geo into politics as a causal term, the compound word conveys exactly the combined sense of geographical determinism and prophetic understanding to which the geopolitician aspires. He (it is almost always so) tells us what is determining and, presumably, in having this expert knowledge, can warn us (those of us on the wrong side of the geography) before it is too late. The contradiction here, of course, is that if we can aspire to do something in the face of geographical determinism then the determinism cannot be absolute but must be also contingent in its effects. Obviously, noting such irony was not Mackinder's strong point, neither is it of his apostles. Gerry Kearns fills us in on how this happened and, more importantly perhaps, on how it can be exploited to create a very different approach to geopolitics in which it is the very contingencies of political economy and geopolitical imagination that become its determining elements. 


\section{Masculinity, “impact” and Mackinder's geopolitics}

\section{Matthew G. Hannah}

Gerry Kearns' book is a model of critical scholarship. As critique, it does political geographers and international relations scholars the considerable service of placing those iconic ideas of Mackinder at least schematically familiar to most of us (the geographical pivot of history, heartland and rimland, etc.) within the geopolitical, intellectual and more broadly cultural contexts of Mackinder's day. We see just how deeply Mackinder's assumptions about the geopolitical world were shaped by his commitment to the project of British Empire. We see how tightly this geopolitical vision was woven with a rather crude racism as well as with a concern for 'masculine' behavioral ideals. Perhaps most importantly, we see that the entire web of positions, priorities and practices out of which Mackinder constructed his influential views was never the only game in town. Through searching discussions of the ideas and activities of Peter Kropótkin, Mary Kingsley, John Hobson, Élisée Reclus, and others, Kearns makes a strong case that there were very different and much more progressive ways to understand the world, its peoples and its politics, even on the basis of many of the starting assumptions upon which Mackinder likewise relied. This elaboration of contemporaneous alternatives is perhaps the most elegant feature of the entire argument.

The implication, of course, is that Mackinder's ideas, however influential, have always been optional. This is brought home very nicely through the main chapters of the book by pairing up each major facet of Mackinder's thinking (social Darwinism, a heavy investment in masculinist behavioral ideals, commitment to Empire, educational program) with parallel but decidedly different approaches to these themes by a series of his contemporaries. In what for me is the strongest chapter of the book, the penultimate chapter entitled "Conservative Geopolitics", Kearns shows in great detail how many strands of Mackinder's basic approach have been revived or recycled in the late 20th and early 21 st centuries and sold to US, British and other publics as natural or inevitable. The final chapter, then, "Progressive Geopolitics", draws together and updates some of the main insights of Mackinder's original opponents to survey the current geopolitical scene from a very different perspective. Here, too, Kearns is very persuasive.

I want to dwell on two related issues, the construction of historical discourses in Geopolitics and Empire, and the importance of cultures of masculinity to the history of geopolitics. In my reading, the discourses contemporaneous with Mackinder come across in the book as only partly anchored in institutional fields of power. In Chapter 2 especially, but throughout the book, Kearns embeds Mackinder himself very thoroughly in relation to the various levers of power and influence. To some extent it is inevitable that Kropótkin, Kingsley, Hobson and Reclus are not so thoroughly contextualized, as the book is not primarily about them. Nevertheless, there is a noticeable contrast between how thoroughly Kearns relates these figures to discursive networks and how little material there is about their political influence. Chapter 3 illustrates this pattern very well. There Mackinder's evolutionist view of the political world is carefully contrasted with that of Kropótkin. Kearns brings to light strong evidence that the discursive formation they both inhabited was in fact riven with real disagreements, that Kropótkin's writings found a broad readership, and that his position had a significant number of adherents. But when it comes to Kropótkin's influence upon the formation of policy in elite circles, or upon government decision-making, no information is provided. Here as elsewhere, the historical narrative does make clear that Mackinder's geopolitical ideas themselves were not predestined to be implemented, but this is a long way from showing that the progressive alternatives stood even a ghost of a chance. There is precious little in the narrative to steer the reader away from the tenacious impression that Reclus, Kropótkin and company would have failed rather miserably on measures of "impact," had there been some precursor to the "Research Excellence Framework" through which open-minded and creative scholarship is now so effectively promoted in the UK. The only remotely likely alternative to Mackinder's conservative imperialism appears to have been the increasingly influential liberal imperialism adopted by, for example, Lloyd George. It was possible, as Kearns shows so elegantly, to think quite progressively at the time, but how possible was it to think progressively and influence geopolitical practice?

There are of course many different ways to approach this question. Here I would like to emphasize masculinist gender norms (bearing in mind of course their intersectional embeddedness). Geopolitical discourse since 9/11 has demonstrated once again the importance of what might be called "trump appeals," themes or figures put forward in times of perceived crisis as so basic that they override "normal" considerations. As some of the literature cited by Kearns in his Chapter 4 makes clear, the purported need to act (or perhaps more importantly, to appear to act) in a "manly" or "masculine" way is a recurrent trump appeal, one which is crucially important in discourses about whether to pursue the use of force or the maintenance of control as opposed to diplomacy, negotiation, or disengagement from a relation of domination. An impressive and troubling illustration of how manly behavioral norms have functioned as a trump appeal in geopolitics is Robert Dean's study of debates in the Lyndon B. Johnson administration about whether to pull out of or stay in Vietnam (Dean, 2001). My suggestion here is that a masculinist discourse pervasive in one guise or another in many European and North American countries in Mackinder's time would have been a serious barrier to the implementation of any truly progressive geopolitics.

Kearns' focus upon a specific set of masculine behavioral norms to explain aspects of Mackinder's geopolitics as well as his insistence on climbing Mt. Kenya is very important. But there were other masculine behavioral norms circulating in Mackinder's time in addition to those highlighted by Kearns. A more extended engagement with geographical writings on masculinism, exploration, science and the mastery of territory, particularly the work of Karen Morin on AGS President Charles P. Daly (Morin, 2008), or my own book about the explicitly masculinist governmental vision of Francis A. Walker (Hannah, 2000), would have helped to further differentiate the field of masculinist options within which Mackinder's specific location can be understood. With the late-nineteenth-century modernization of techniques of extended territorial governance in the British Empire, the United States and elsewhere, a new suite of masculine roles was in the process of being consolidated, variants of the rational, all-surveying administrator of space. This figure complicated any simple mapping of masculinity or its lack onto a distinction between "the field" and "the comforts of civilization." The omniscient administrator was not ensconced in a cushy, smoke-wreathed gentlemen's club but busily marshalling previously unheard of epistemic resources in the head offices of the scientific or governmental knowledge gathering institutions that were transforming London, Washington DC or Paris into vast centers of calculation. Many of the men who adopted some variant of this subject position did so through a revolving door linking government to the halls of academia, so it would have been at least a thinkable path for Mackinder.

Mackinder shared much with other "men of science," particularly in his belief that the demands of modern life in a powerful country posed new challenges to national education systems. As Kearns shows in Chapter 6, Mackinder was keenly interested in tailoring the British educational system to the cultivation of citizens simultaneously appreciative of their democratic responsibilities at home 
and equal to the demands associated with running an empire. Mackinder's career path diverged from those of scientist-administrators, though, in his assumption of a specifically legislative, as opposed to administrative, position in government, and in his short-lived mission to the contested fringes of imperial territory. Both of these experiences were quite obviously shaped by the contending forces of politics, and would have made it more difficult for Mackinder to style himself a cool, rational man of science surveying the scene from the Olympian heights of detached objectivity. He did link into the project of scientific inventory on his Mt. Kenya expedition. But as Matthew Edney shows in his study of the mapping of British India, the subject positions associated with objective field observation were different from those associated with objective compilation and interpretation of knowledge in the metropole (Edney, 1997).

All of this is a roundabout way of saying that Geopolitics and Empire tends to limit what counted as masculine performance to the nexus of exploration and violent contest with nature and natives linked in Mackinder's thought and practice to conservative imperialism, whereas there were equally prestigious masculine roles available to the rising territorial administrators of liberal empire. Both masculine types, however, remained invested in control and mastery of one sort or another, and I would suggest that, in Mackinder's time at least, to reject these overarching goals was to locate one's geopolitical vision outside the realm of the potentially influential. This, I believe, helps explain why the visions of Kropótkin, Kingsley or Reclus were never very likely to animate British or other great power geopolitics at the time.

The latter part of Kearns' book, which brings geopolitical questions into the present, culminates in a powerful exhortation to refuse the naturalization of neoliberal empire or conservative geopolitics as the only possible systemic arrangements for the 21st century. Here he is able to make a stronger link between progressive ideas and impact than in his account of Mackinder's context. He does not neglect to include a feminist critique of masculinist gender ideals in this exhortation. But here, as earlier, I would propose that the importance of this dimension be amplified. It is not too much of a simplification to say that the three pillars of currently hegemonic geopolitics most desperately in need of replacement are the ongoing attempt to naturalize neoliberal capitalism, the ongoing ravages of racism and its dispossessions, and a preferential resort to means of violence and coercion which is closely linked with masculinist assumptions, and which arguably underpins the other two in crucial ways. Gerry Kearns has opened up an extremely promising avenue for exploring some of the roots of these developments in the geopolitical discourses of an earlier age. Ongoing critical scholarship will undoubtedly continue to refine our sense of how best to think about these tenacious patterns in order to overcome them.

\section{Situating progressive geopolitics: culture, politics and language}

\section{Joanne Sharp}

This is an important book that challenges the inevitability in conventional historical accounts of the development of dominant ideas - here Mackinder's geopolitics - by juxtaposing these ideas with those of contemporaries whose understandings of the world, and their normative visions for how it might be better, promised another way.

Kearns' book develops toward his vision of Progressive Geopolitics, an alternative to Mackinder-inspired Conservative Geopolitics. For Kearns, Progressive Geopolitics:

[S]upplements the vision of the world that counts as reality within Conservative Geopolitics by: adding a recognition of the scope of non-force alongside the study of the role of force in the world; including a review of other institutions that operate internationally beside states; $[. .$.$] acknowledging that there are$ more ways that goods and services are produced and supplied than as commodities and through unregulated competition $[; \ldots$ and $]$ recognizes that the most effective ways to resolve global issues without resorting to force often involve multilateral institutions (Kearns, 2009: 266).

Thus, Kearns avoids the trap of some guises of critical geopolitics whose restless and unending critique has led to charges of political nihilism. Progressive Geopolitics is not afraid to say that there is a better way of doing things and, as such, is a powerful vision indeed.

As someone who has been associated with the emergence of critical geopolitics, but who has become disillusioned with the political implications of its development, I find the challenge presented by Kearns' book important. In light of my own ambivalent relationship with critical geopolitics, I want here to offer three engagements with Kearns' book: the role of geopolitics in political culture; the political meta-values of Progressive Geopolitics; and, finally, the implications for how we do our critical geopolitics.

To begin with geopolitical culture: one of the most important aspects of the arguments in Geopolitics and Empire is Kearns' development of Mackinder as an imperial subject. This is a key, but underdeveloped, area for study, as it unpacks how global-scale geopolitical ideas relate to the constitution of individual identity, and thus how individuals understand their role as citizens within the nation-state, and the role of the country within international society. It explores, in other words, how individuals are interpolated to become subjects of dominant political discourse and, in the case of Mackinder, go on to replicate this discourse through political praxis.

In Geopolitics and Empire we move from discussion of the end of the 19th and first part of the 20th centuries to the present with much less emphasis paid to the Cold War. But I would argue that the reason that post-Cold War leaders could still draw upon geopolitical language - that they could still draw upon the Conservative Geopolitical discourses of inevitability of force and conflict was because of the embedding within American political culture of Cold War geopolitical ideas (see Sharp, 2000 for an example of this). While the language of geopolitics puts a great deal of emphasis on force, the cultural hegemony of the geopolitical imagination is no less powerful.

Historicizing geopolitics through the Cold War period is important because this again counters the inevitability of geopolitical logic. Geopolitical language was produced and reproduced during the Cold War and then lingered on in the aftermath because new forms of explanation had yet to emerge (see Agnew \& Corbridge, 1995).

Although this view is still found in all sorts of powerful institutions and individuals, it is in no way unchallenged, as evidenced by the huge anti-war marches of 2003, extensive critiques of Bush and Blair, and the fact that nearly one in four UK citizens recently indicated they wanted Blair tried as a war criminal (Norton-Taylor, 2010). The zero-sum geopolitical map of power-politics does not have the same overwhelming influence in Anglo-American political culture as it did during the Cold War. And, if we look at the geopolitical imaginations of non-Anglo-American societies, it becomes clearer still that other visions are not only possible, but are being asserted and enacted around the world (for example, see the work of geographers (amongst others: Featherstone, 2008; Fluri, 2009; Oslender, 2007; Routledge \& Cumbers, 2009), the writings of Arundhati Roy (e.g. 2002), or Riverbend's blogs from Iraq).

Turning now to the meta-values of Progressive Geopolitics, I would question whether Progressive Geopolitics is possible or, to be devil's advocate, whether it is even desirable. In other words, 
to what extent do we want to work within the existing structures of states and international actors? As noted earlier, Progressive Geopolitics aims to supplement the vision of Conservative Geopolitics, but will this reformist position get us where we want to be? As noted at the outset, this tension between wanting to make directed political interventions and the imperative to critique is not unique to Geopolitics and Empire.

What are the political values which underwrite Progressive Geopolitics? They are not spelt out and the interlocutors that Kearns provides to challenge the inevitability of Mackinder's vision - Kropótkin, Reclus, Hobson and Kingsley - do not make easy bedfellows. Instead, I think that Geopolitics and Empire assumes that we all know where we want to go. It is a modernist, Enlightenment project based around progress and justice in the political and economic realms. On the face of it, that's uncontroversial. But, whose values are these?

And this is where, despite on one level not being able to disagree with any of the laudable ambitions of Progressive Geopolitics, I do start to get anxious. For, if feminist and postcolonial theory has taught me anything, it is to be wary of any prescriptions of how "we" should progress - history is littered with the victims of such good intentions. So, here is where I do want to return to a more radical and restless critique characteristic of feminist versions of critical geopolitics, which insists upon the multiplicity of possible futures.

Kearns claims that Progressive Geopolitics is informed by perspectives, which include "those excluded from the privileges of power" (p. 266). But I do not see the mechanisms for how these different voices get heard. If Progressive Geopolitics supplements rather than deconstructs Conservative Geopolitics, then is there the danger of simply co-opting these other voices and experiences rather than being radically open to views which might offer more thorough challenge? What about those whose experiences of international organizations have been of exclusion or who have only been allowed around the table when they translate themselves into metropolitan language and convention (see Briggs \& Sharp, 2004)?

In reading Geopolitics and Empire I still get the feeling that Kearns, like Mackinder, sees geography as an aid to statecraft, but as an aid to a progressive state; where Mackinder might have sought to aid Bush, perhaps Kearns' vision is one better suited to Obama.

Finally, taking up the question of how we actually do our geopolitical analysis, I note that we have, as critical geographers, tended to be rather self-effacing when it comes to embracing our roles as public intellectuals, but perhaps it is time to think much more about using our authority, rather than anxiously denying it. But, we need to think carefully about how we write. To use one of Kearns' alternative voices as an example, Mary Kingsley was able to write only by including self-effacing comments to ensure she was not seen as too competent or too much of a challenge to masculinist authority. Humor like hers can be a powerful political force, but it is easily misread. What to 21 st century feminists is a powerful ironic narrative, in other contexts, reinforces a sense of silly headed femininity.

Conservative Geopolitics uses a language of reason, objectivity and inevitability. At its heart is "common sense". Geopolitical experts reduce complex arguments to the simplicity of right and wrong, and true and false. This form of knowledge production is very different from critical social science, which seeks always to open up the apparently self-evident to examination, and to expose the omissions and assumptions that allow common sense to function. Critical texts are never closed or complete like common sense. So, we face a challenge not only in offering different explanations of the world, but the very language that we use. How can we engender a desire in people to want to tackle the difficult, complex and open nature of critical analysis rather than the cut and dried presentations of common sense, which does all the work for its audience? Kearns has been exemplary in this respect, communicating his
Progressive Geopolitics in a much wider realm of publics than is typical of critical geopolitics, with sites ranging from BBC's Radio 4 to the magazine Wired.

\section{Mackinder's legacy!}

\section{Peter J. Hugill}

In his preface to this landmark book Kearns sets out both his crucial intellectual contribution and the crucial intellectual tensions it embodies. He does so via Christopher GoGwilt's work on Joseph Conrad, which operates at the intersection of literature, culture, and the intellectual and geopolitical histories of the turn of the 1900s. For GoGwilt, "Conrad's work reveals a doublemapping, whereby a newly European idea of the West-borrowed from the terms of Russian debates-distorts the worldwide shattering of cultural traditions at the turn of the century by an attempt to reconstitute historical discontinuity as the continuity of 'Western history”' (GoGwilt, 1995, 3). This is Kearns' first tension. The second is that whereas Conrad's earlier work, typified by Heart of Darkness (1899), focused on the "new imperialism" of the late 1800s, his later work, such as The Secret Agent (1907), shifted focus to the revolutionary responses to that new imperialism.

Mackinder was one of several possible intellectual and cultural products of his time and place, in which, GoGwilt argues, many had ceased to believe, as they had earlier, that Enlightenment values would diffuse from Europe to the rest of the world, and that Europe was an integral part, albeit the leading edge, of a universal history of humankind (GoGwilt, 2000). By the late 1800s, however, that belief was increasingly challenged by anti-colonial movements and insurgent nationalisms. Rising European imperialism and GoGwilt's "fiction of 'geopolitics'," locates the geopolitics espoused by Mackinder as representing the increasing identification of Europeans with a very different view of the West. Mackinder's geopolitics argued for a European exceptionalism in which the unique history of the West was threatened by the geopolitical "other," notably an East "in opposition" to the West in the manner identified by Edward Said as Orientalism (1979). As Kearns notes, Mackinder believed that, ultimately, only force could maintain Europe's privileged position both against indigenous peoples and, since the world had "closed" in terms of geographic expansion, against other European empires competing for resources in what Mackinder saw as a Darwinian zero-sum game.

In following GoGwilt's line of reasoning Kearns modifies and expands on Agnew's discussion of Civilizational and Naturalized Geopolitics. The main elements of the Civilizational Geopolitics of the early 1800 s were "A commitment to European uniqueness as a civilization; a belief that the roots of European distinctiveness were found in its past; [and] a sense that though other cultures might have noble pasts with high achievements, they had been eclipsed" (Agnew, 2003: 87). The Naturalized Geopolitics of the late 1800 s saw "a world divided into imperial and colonized peoples, states with 'biological needs' for territory/resources and outlets for enterprise, [and] a 'closed' world in which one state's political-economic success was at another's expense" (Agnew, 2003: 94). Agnew sees the shift from Civilizational to Naturalized Geopolitics as occurring around 1875 , driven largely by internal European forces. For Agnew, Mackinder was reacting against the collapse of the European Concert that created at the Congress of Vienna, the rise of competing European Empires, especially newly unified Germany, and the consequent loss of British hegemony. There is much to this, but Kearns' argument is more existential and convincing than Agnew's. Mackinder was driven not only by fear of a British loss of hegemony but also by a much deeper-seated (and unstated) fear of a European loss. 
As Kearns makes clear, there were other possible reactions to this existential fear. Socialists, anarchists, and feminists such as Hobson, Reclus, Kropótkin, and Kingsley clearly espoused far more culturally inclusive views of humankind, and not just as individual scholars sympathetic to the world outside Europe: all were connected to institutional movements within Europe that argued against the sort of solutions based on force inherent to colonial imperialism. At their extremes such alternatives to imperialism were revolutionary, as Conrad understood at the time.

The point of this tension is well taken, but the book fails to answer several questions. First, is imperialism (at least in the modern world) only and always a response to anti-colonial movements and insurgent nationalisms, or is it more complex? Is, for example, Colonial Imperialism of the sort espoused by Mackinder just such a response? In Kearns' presentation, Liberal Imperialism seems an attempt to hold on to the Enlightenment belief that such core, liberal, European values as openness to foreign direct investment, lack of aggressive impulse toward other states, and democracy could continue to diffuse, albeit under more control from the parent country (Kearns, 2009: 233).

Second, should one view Reclus, Hobson, Kingsley, and Kropótkin as clinging to Enlightenment values, or their vision as something new? Such revolutionary forces as socialism, feminism, and anarchism began to move to the forefront of western social thought just as confidence in the liberal ideals that drove the earlier 1800s-Agnew's Civilizational and Kearns' Liberal Geopolitics-was declining. Socialism, feminism, and anarchism seem like updated, modernized versions of an Enlightenment conviction that European ideas were naturally superior. Kingsley's feminism may be willing to celebrate cultural diversity, but hardly at the price of accepting, for example, the clearly discriminatory practices of Islam toward women.

A third question arises from the fact that, for Mackinder, a major justification for colonial imperialism was the Social Darwinism of the late 1800s. Mackinder saw international relations as shaped by history, environment, and race (and race was itself shaped by environment working over historical time-not in the crude way suggested by Ellsworth Huntington, but very much a force subject to cultural control). Underpinning this Darwinism was a force Kearns does not address but Mackinder must have been aware of, the Malthusian trap that seemed to be staring the world in the face as world population outpaced agricultural output. By the late 1800s, the British were well aware they were importing massive amounts of both foods and agricultural raw materials, especially cotton. Much of this was sourced in the Empire. To a contemporary Briton Colonial Imperialism would have seemed a necessity. Hobson summed up exactly that view when he noted that many of his contemporaries believed that "an ever larger share of our population...is...dependent for life and work upon food and raw materials from foreign lands" (Hobson, 1938 [1902]: 71-72).

Other solutions to the food and raw material supply problems than colonial imperialism were suggested at the time. Hobson argued that British imperialists were "like the slovenly farmer...ignoring the political and economic wastes and risks involved by this imperial career" and that they should "put brains into agriculture" like Denmark or Switzerland (Hobson, 1938 [1902]: 92-93). More often, however, solutions were embedded in the new, Racialized Geopolitics rather than the simple economics that drove much of Liberal and even Colonial Imperialism. In Mutual Aid (1902) Kropótkin suggested that evolutionary selection operated through the struggles of entire species against their environment, that cooperation was an evolutionary advantage, and that adaptive mutations were Lamarckian in rate, not Darwinian (Kearns, 2009: 69). For Kropótkin, geographic expansion, thus imperialism, was completely unnecessary. He argued that, when the revolutionary social principles of
Anarchist Communism were combined with scientific agriculture, "the $3 \frac{1}{2}$ million inhabitants of the two departments round Paris could find ample bread by cultivating only a third of their territory" (Kropótkin, 1968 [1913]: 278).

Kropótkin's problem was his insistence that evolution was based on the fitness of the group. This arguably leads to espousing another set of revolutionary ideals: which groups are fittest to inhabit the earth and who should have the right to membership in such groups? The combination of such racial theories with a perceived need to increase the supply of food and raw materials led Hitler to argue for a policy of geographic expansionism that, at the height of Racialized Geopolitics, went far beyond Colonial Imperialism: that "soil exists for the people which possesses the force to take it and the industry to cultivate it" (Hitler, 1971 [1925]: 134). Ultimately, of course, a very different set of revolutionary Germans solved the immediate problem of the Malthusian trap and ensured the worldsupply of food and agricultural raw materials kept pace with population via the rapid development from the late 1800s on of an organic chemistry that delivered not only nitrogenous fertilizers but also, ultimately, synthetic fibers such as polyester (Hugill \& Bachman, 2005; Smil, 2001). Science and technology thus made geographic expansion, colonies, and territorial forms of imperialism unnecessary, as some recognized in the 1930s (Hugill, 1993; Zischka, 1936).

In his last two chapters Kearns provides a thorough analysis of the Conservative Geopolitics propounded by Mackinder and picked up by the Neoconservatives in the United States, especially during the administration of President George W. Bush. Clearly, Conservative Geopolitics in both late 1800s Britain and late 1900s America was a response to existential fears of decline and the non-western other. But what, then, is Progressive Geopolitics? Transnational corporations (TNCs) and non-governmental organizations (NGOs) may be becoming important relative to territorialized polities, but TNCs are not new, as the East India Companies of the Seventeenth Century attest. Organizations like the United Nations are clearly a continuation of the Enlightenment project, one prefigured by numerous calls for some form of global NGO that date to the early 1900s, such as King Camp Gillette's World Corporation (1910) on the right and the International Workers of the World on the left (Hugill, 1993).

It is clear that the recent attempt by Neoconservatives in the United States to revive a Conservative Geopolitics of the sort Mackinder would recognize has failed, at least for the moment. The revolutionary alternatives of Anarchism, Communism, Fascism, and Socialism have also failed, and Feminism, though clearly successful in the West, has never seemed a particularly compelling worldview. But is Progressive Geopolitics of the sort Kearns espouses a radical improvement? It seems at first sight rather like old wine in a new bottle, the Enlightenment project revved up for the twenty-first century, effectively a revised version of Liberal Imperialism with more legal protection for the rights of indigenous peoples. Inasmuch as "global political relations can only be understood as part of a global political economy" (Kearns, 2009: 295) it is difficult to avoid the conclusion that the world needs a hegemonic power. Since hegemonic powers tend to some form of imperialism, even if only cultural imperialism, a liberal version of that will be a great deal better than a conservative one.

\section{What would Mackinder think of the state of geography today?}

\section{Lorraine Dowler}

As I started to write this essay I realized that it was going to be a far greater challenge than I realized. As I read Kearns book, I appreciated how little I really knew about the life of Halford 
Mackinder. However, my reading prompted me to reflect on the current state of discipline and question what Halford Mackinder would think of it today. Therefore this essay offers a set of reflections rather than a scholarly intervention. As I read I wondered if Mackinder would have been saddened to know that when I haphazardly quizzed graduate students around the department about "Who was Halford Mackinder?" most of them, like myself, had only a vague idea? Perhaps he would have been more distressed of knowing that a female geographer had posed this question and that the field-of-study he had appreciated as a "manly endeavor" was evolving.

I appreciate how Kearns also attempted to bring Mackinder's thinking into the 21st century by drawing parallels between Colonial conquest and U.S. imperialist actions in the War on Terror. For this reason, I would recommend Kearns' examination of Mackinder as a "must read" for every graduate student entering the discipline; not simply for his critical analysis of geography's imperial past but for his ability to point to discursive parallels of imperialism with contemporary modes of conquest. I say this for several reasons. First, his thesis provides evidence of the seamless relationship between geopolitics and British Imperialism, Nazi expansion, the Cold War and the contemporary War on Terror. Second, for a discipline that at times has difficulty in making connections across its sub-fields of study, Kearns' discussion of Mackinder's training as a physical and human geographer (p. 42) implicates the discipline, en masse, in the quest for territorial expansion. As Kearns argues, the "treatment of evolution within the humanities, that Mackinder found at Oxford, was broadly Social Darwinist and it reinforced the assumptions of racial inequality upon which rested the Empire" (p. 42) and thus Kearns demonstrates the interdependent nature of education, humanities and science on one hand with the process of militarization on the other (p. 3). Lastly, although not specifically identified by Kearns, his discussion of a progressive geopolitics triggers, at least for this reader, some thought-provoking questions about the current state of the discipline and its relationship to issues of political practice.

As I read through Geopolitics and Empire, I identified some parallels between Kearns' reading of Mackinder and some feminist assessments of contemporary modes of militarization. It is important to note that I am not offering this discussion of Kearns' thesis as a critique of any absence in his work. Instead, I contend Kearns investigation initiated some insights that, as a feminist geographer, assist me in how I think of my own work and how I view some contemporary trends within the discipline of geography. Consequently this essay will engage two themes. First, I will explore some of the ways in which Kearns and feminist analysis of geopolitics parallel and push each other to provide an enhanced understanding of geopolitics, militarization and empire building; and second I will suggest some ways the discipline might be sustaining these processes today.

As suggested, I begin with the parallels between feminist scholars' concerns with militarization and Kearns' argument that, during the period of imperialism, geopolitics viewed force as more than simply necessary but inevitable! Kearns skillfully illustrates British Imperialism as a "manly endeavor" and details how Mackinder argued against the admittance of women to the Royal Geographical Society due to "women's lack of robustness for scientific exploration" (p. 100). Kearns asserts that gender most certainly shaped the political imagination of the period. Furthermore, he details Mackinder's attitude that the role of British women in the colonies was "great imperial work" and that women were necessary to maintain the domestic realm to free men to pursue the spoils of imperialism, unregulated by feminism.

As part of his analysis Kearns examines the famous African mountain climbs of Mackinder and Kingsley and evaluates how very similar feats were presented in gendered ways. Kingsley, as Kearns argues, pushed through the climb by reflecting on the memory of her dead father while on the other hand Mackinder was on a manly adventure, doing what men were suppose to be doing, conquering the natural environment, as men would conquer the supposed wilds of Africa. Feminist scholars have noted that historically during times of heightened nationalism, women who have crossed into the public sphere in transgressive ways, like Kingsley were usually explained away, as being driven by the ghosts of dead fathers, husbands and sons (Ward, 1995).

As Kearns argues, "there are striking parallels between the geopolitical ideas animating those who advocate the consolidation or even extension of the global influence of the United States today, and those who a century ago took up a similar stance on behalf of Great Britain." (p. 3). Although Kearns does an excellent job of detailing how masculinity aided in the establishment of the global influence of Great Britain, he does not carry this analysis over to the discursive ties he suggests with the War on Terror. For example, Mackinder's thesis of the natural vigor of manly men for great adventure is rearticulated today in the United States military policies on exclusion. Illustrative of this would be the current "don't ask, don't tell" restrictions on gays in the military and the limitations placed on women to non-combat roles. These policies can be viewed as a rearticulation of the political imagination of conquest. For instance, though women are designated to "support" roles in the military they are indeed dying as a result of their close proximity to the frontline. As a nation we find comfort when women are assigned to support roles (helpmates) even if they happen to die as a result of those roles. Under “don't ask don't tell" and combat exclusions laws, the notion of the heterosexual male warrior remains unscathed. These gender tropes are integral to the American imperialism and expansion that Kearns so vehemently critiques.

As well, Kearns contends that Mackinder was constant in his belief that women should not be admitted to the Royal Geographic Society. Mackinder also wanted to restrict women in wider society and was against women acquiring the right to vote. Today, we can see similar issues with the gendering of wider society, as it relates to the process of militarization, in that the militarization of society is not simply questioning the roles of women in the armed forces but the societal attitudes toward the establishment of gender roles within wider civil society (Dowler, 2002; Enloe, 2007). For example, if women were equally participating in contemporary foreign policy of conquest and expansion then what would happen to the political imagery of protection of the domestic sphere or the home?

Consequently, I propose as a discipline we question how notions of contemporary geographic expansion are framed as the protection of the domestic. As Cowen and Gilbert suggest, the concept of the homeland has been reinforced since 9/11 and that metaphors constituted from notions of family have been invoked to promote national security initiatives across scale. They examine how a "normative nuclear family" has become a central focus of U.S. political imagination. As result the understanding of the heteronormative nuclear family has been evoked to mobilize a domestic response. For this reason, they assert the loss of the traditional family and the loss of the nation have been conflated producing a vision of the neoliberal family as (the only) good citizens. For Cowen and Gilbert, the family metaphor is skillfully manipulated by the state to create a fear of a culture of dependency (Cowen and Gilbert, 2008). Representations of the independent neoliberal family become a central strategy whereby the lack of a strong family structure would weaken the nation to our enemies. Therefore, I see an argument for a case of historical repetition in terms of how Mackinder was employing gender in relation to statecraft and how it is currently being employed during the War on Terror. 
As a second part to this commentary, I think it is important, as a discipline, to be aware of how we may continue to be aiding statecraft and empire building. As stated earlier, Kearns argues that Mackinder was steadfastly against women entering the Royal Geographic Society because it would feminize, hence weaken, the organization. But, hasn't parts of contemporary human geography been feminized, such as political, cultural and historical geography, in favor of the manly endeavors of geopolitical analysis. The feminist critique of geopolitics is relatively nascent and has had a slower level of integration than compared with other subareas such as cultural and urban geography (Dowler \& Sharp, 2001). Not surprisingly, at the annual meeting of geographers in Washington D.C., many feminist scholars noticed the absence of feminist analysis in sessions focused on the New War, while sessions focused on the everyday manifestations of militarization were overwhelmingly attended by feminist scholars. This prompted a discussion in the final militarization session about why there seems to be a rift between geopolitical inquiry and feminist political interventions. As part of this discussion there was a general belief that it was still difficult to publish feminist work in the flagship political geography journal. To this end, one can only surmise that even today, the area of geopolitical inquiry remains somewhat masculinist and therefore constitutes a frontline of intervention for feminist scholars.

Finally, the last critical question Geopolitics and Empire raised for me is: How are we teaching against empire in our classrooms? Kearns argues, "Geographical education would train young people in the strategic gaze of the fox-hunter and the solider and, ultimately, they would, through Mackinder's school-books learn to encompass the world with this geographical imagination and thereby develop an imperial vision" (p. 164). Geography as a discipline finds itself at a crossroads of teaching a progressive geopolitics, to unearth contemporary acts of imperialism, racism, sexism and homophobia. While still aiding the state through certain types of educational programs, such as geospatial intelligence education.

In the beginning of this essay I asked: "What would Mackinder think of the state of the discipline today?" I would dare to speculate that he would have mixed feelings. He would most likely be reassured to know that the area of geopolitical inquiry still remains a manly endeavor (Laliberte, Driscoll Derikson, \& Dowler, 2010). However, I would surmise that he would be greatly disheartened by the important research being conducted in the area of critical geography, focusing on destabilizing issues of militarization, which aid in the establishment of sexist, racist and homophobic discourses. I would include Kearns' insights into Mackinder as an important addition to this critical body of work.

\section{Progressive historiography}

\section{Gerry Kearns}

Hannah, Sharp, Hugill, and Dowler pay me the compliment of identifying important issues with which my book engages and each also reminds me of work of their own that takes up these matters in ways that either complement or challenge my own emphases. I am grateful for the opportunity to elaborate on some of the methodological choices that I left implicit within the book itself.

I adopt what Berdoulay calls a contextual approach and try to produce what Dean refers to as critical and effective histories (Berdoulay, 1981; Dean, 1994; Kearns, 2007, 2008). A contextual history of Geography is one that relates geographical ideas to the political, moral, economic, and other circumstances that explain the demand for certain perspectives, why they achieve salience in particular periods. By a critical history of Geography I mean one that stresses the contingency of events and developments to make evident the political and ethical choices that directed the development of the discipline in different times and places. By an effective history of Geography I mean one that relates this contingency to the unrealized potential of the present (Kearns, 1998). Alternative geographical perspectives were and remain possible and past alternatives can provide a resource for thinking about alternatives in the present. Past institutions, networks, and spatialities share many features with the present and continuities between past and present significantly shape geographical imaginations. Specifically in Geopolitics, the field of geographical reasoning that my book addresses, there have been over the past century or so continuities in global relations which have meant that influential commentators often refer to the works of earlier thinkers in support of their own arguments. In this manner we may speak of the influence of earlier theory on later ideas but earlier thinkers may also be unconsciously echoed in later writings. Common goals often result in similar justifications being produced in different contexts as advocates for a given strategy try to present it as so overwhelmingly the correct choice that it can appear to be an inevitable choice (Kearns, in press). Thus, in naturalizing imperialism thinkers in very different contexts develop arguments that echo loudly those of Mackinder because he set out one of the strongest cases for imperialism as the necessary route to national survival and others wishing to argue the same will hit upon many of the same points.

I take the thought and legacy of Mackinder as the occasion for my contextual, critical, and effective history of Geopolitics. To begin with, I establish the political, social, and economic context of Mackinder's work through an examination of the perceived and real crisis of the British Empire in the period 1880-1920 and the ways that Mackinder registered this crisis and took up educational and political work to address it. Secondly, I try to make this a critical history by identifying a series of thinkers who, although they shared many of the intellectual assumptions of Mackinder and although they likewise saw imperialism as crucial in shaping global relations between peoples, did not share Mackinder's vision of the inevitability of conflict and exploitation. Finally, I try to make my history effective by tracing the legacy of Mackinder through to the present and by identifying two sets of polarities that do not necessarily map onto one another (as inferred by Hugill). The first polarity is between Colonial Imperialism and Liberal Imperialism. I identify imperialism in processes abridging the sovereignty of people in one place for the benefit of people in another place and I distinguish between colonial and liberal variants on the basis of the justifications that are offered in their support, with colonial imperialists frankly avowing their own self interest in exploiting others and liberal imperialists insisting that their interference in the affairs of others is in service of the best interests of those others. The second polarity is between a Conservative Geopolitics that builds upon Mackinder's insights and a Progressive Geopolitics that might develop those of the alternative thinkers I discuss. What is conservative about the first of these approaches is that it serves explicitly and implicitly to promote global inequalities that maintain contemporary privileges of the wealthy and powerful whereas the latter seeks to address these inequities and make a case for mitigating them. I will now take these three aspects of my approach (context, critique, and effectiveness) to address the remarks of the commentators.

I begin with context and here I note that Hugill specifies the crisis of Mackinder's world in a rather different way than I or Mackinder did. Hugill suggests that the crisis of Empire was really a symptom of a broader Malthusian trap in which world population 
growth was outstripping global resources in ways that were resolved ultimately by technology. On Hugill's reading, imperialism, then, can be seen as a conflict over the size of the slice each state gets whereas the true resolution of the crisis lay with the scientific cooks who baked a bigger pie altogether. In fact, I insist upon the fundamentally imperialist character of the crisis precisely because the balance between needs and resources is always a matter of distribution. There has never been a global balance struck and the imperialist character of Mackinder's thought is explicit in the ways he sought to privilege the needs and comforts of the British people. For Mackinder, the crucial questions were: which people lived well, where resided the shareholders of the companies that made profits from international trade, and whose will prevailed in struggles over access to resources and the control of trade? These questions of distribution continue to shape life chances in different parts of the world regardless of the global adequacy of food, materials, or energy.

Turning from a contextual to a critical reading of the past, Hugill, Hannah, and Sharp each raise questions about the limits of the alternative available from the works of Mary Kingsley, John Hobson, Peter Kropótkin, and Élisée Reclus. Hugill makes the point that although Liberal Imperialism may be different from Colonial Imperialism they are both imperialistic, but in arguing for a Progressive Geopolitics I am not arguing for Liberal Imperialism. For me, the historical thinkers I mentioned, as well as others, offer resources for a Progressive Geopolitics precisely because of their criticisms of various aspects of the imperialism of their own day. Beyond this I register explicitly my own concern over the ways some of them sought to justify on occasion certain other aspects of contemporary imperialism, in colonial (Reclus) or liberal (Hobson, Kingsley) forms. However, I cannot follow Hugill in equating Kropótkin with Hitler, because Kropótkin focused upon the struggle between a group and its environment, a struggle that could be managed successfully on the basis of cooperation and that, therefore, explicitly did not entail aggressive competition with other groups in neighboring or distant places. In emphasizing their critical relations with the theme of imperialism, I did not take up the alternative, valuable and interesting matter of the overall bearing of their ideas upon the issues of liberalism and the so-called Enlightenment project more generally.

Hugill notes that in various ways the thinkers I discuss as alternatives to Mackinder had links to institutions and movements that sustained opposition to certain aspects of violent colonial imperialism although this is certainly underdeveloped in the book. Hannah is right that such a discussion would help flesh out the nature and limits of the alternative contingently available at the time Mackinder wrote. Hannah suggests that one way to do so is to pay attention to the different forms of masculinity beyond the moment of exploration that I highlighted, to comprise rational bureaucracy and the gentleman's club and I would add two distinctive spheres of masculine endeavor that I did sketch briefly, parliament and the university. Hannah proposes that within all these spheres a pervasive masculinity probably rendered alternatives to imperialism little more than intellectual exercises. Sharp identifies a further lacuna when she insists upon the need to move beyond academic texts to the popular media outlets that enable a geopolitical culture to become part of a society's common-sense view of the world. Taken together these remarks highlight the need to say more about how some ideas become dominant and influence foreign policy while others are marginalized.

In my book I specified some of the personal and political networks that Mackinder cultivated and that were part of his effectiveness. For example, I described his work within education precisely as a way of making an imperial worldview part of the common sense of every British child. In terms of the results of all this activity, I described the ways that Mackinder contributed to the successful case for an arms race in the years leading up to the First World War but I also registered some of the limits of Mackinder's influence over the anti-Bolshevik policy of the coalition government that followed the First World War. It would be possible to say more, of course; to look at the various schemes to promote emigration by British people to other parts of the Empire, to consider the relative ease with which young people of all classes were summoned to arms with the declaration of war in 1914, and to look, for example, at Mackinder's own efforts as a military recruiter during the First World War. Turning to the alternatives to imperialism, I did try to show how the anti-racist humanism of Roger Casement, as well as of Hobson, Kingsley, Reclus and Kropótkin, built upon the ideology and the practice of the anti-slavery movement and I do think more broadly that alternatives to imperialism could be imagined largely because anti-colonial practice in Ireland, India, and Egypt, for example, and anti-racist sentiment as developed within certain strands of evangelical Christianity and through the example of African-American writers and artists, had already made it possible to conceive a fellowship of humanity that transcended race. The war-weariness that followed the First World War was certainly fed by these oppositional movements and it placed serious limits upon the imperial adventuring of the British government in subsequent years. The links that Hannah identifies between masculinity on one hand and the related strategies of violence and control on the other are close and their joint operation is indeed powerful but while hegemonic in many rich countries this nexus is subject to occasional check.

When we turn from critique to effectiveness, the responses suggest I should perhaps say a little more about my decision to focus upon imperialism rather than upon the nature of the West, or upon the forms of liberalism, or upon the Enlightenment project tout court. With Sharp I register a certain dissatisfaction with Critical Geopolitics but my own unease is that the focus upon epistemological questions (undermining once again any claims to a singular truth about the global order) still leaves us in need of critical accounts of international relations. Here I suggest that one way to address the tendency of Conservative Geopolitics to make global inequalities appear "natural" is to pay some attention to ontological rather than epistemological matters. The naturalizing of capitalism, imperialism, and racism operates precisely by closing down our imaginations, causing us to accept a very particular and limited account of reality. In this fashion, Mackinder chose to distinguish between 'democratic ideals and reality' (Mackinder, 1919). In sum, conservative politics insists that there is no alternative to these iniquitous arrangements. In response I offer my account of Progressive Geopolitics as a supplement to Conservative Geopolitics. I am saying that, yes, the phenomena to which conservatives attend (force, conflict, etc.) are indeed part of the global relations that shape our lives but they are not the only phenomena which should command our scholarly and political interest. Thus the conservative posture of dismissing social justice, non-commodity economic relations, international law, and human rights as merely idealistic is blinkered and misleading. In other words, there continues to be a material basis for the alternative perspectives that may be developed further from the ideas of Hobson, Kingsley, Kropótkin, and Reclus.

My focus upon imperialism also inflects where I direct Progressive Geopolitics. Sharp worries that I am saying that I know where we need to be going and that I am seeking to impose an Enlightenment project upon others. I am more narrowly interrogating the ways that rich and powerful countries compromise the sovereignty of other states and peoples. It is on the basis of our interactions with others that I think we acquire obligations toward them and these obligations relate both to the nature of our interactions and to 
the nature of the consequences that follow from our actions. Because the rich countries compromise the sovereignty and abridge the life chances of people who live elsewhere, the citizens of rich countries have an obligation to offer recompense to those they have harmed and an imperative duty to desist from doing this harm when they learn of it. I wish to see the rich countries govern their own behavior consistently with the values they claim as their own: tolerance, respect for the sovereignty of others, attention to the needs of the least fortunate. I believe that rich countries have the right to offer asylum to people perceived as being treated badly under their current government. Beyond this, and short of direct action to halt crimes against humanity, powerful countries have few grounds for intervention and certainly should not presume to impose democracy or capitalism at the barrel of a gun. In particular, I believe that other people should leave well alone the land, resources, and lives of the world's first-nations or indigenous peoples. I am certainly not advocating any form of imperialism which was, indeed, the intended focus of my critique.

This brings me back to Geography and Dowler's excellent suggestion that scholars and educators consider the continued entwining of Geography, masculinity, and imperialism in their work. I do make a few remarks on this in the book and I continue to reflect upon these issues (Kearns, 2010). With one eye upon how my book might be used in the classroom, I made the conscious choice not to spell out the methodological context and choices because I wanted the book to raise issues rather than be read as an example of a particular approach. Geographers can certainly have a useful discussion with their students about the epistemological arrogance of Western Enlightenment and its claims about singular truth. However, geographers can also talk about what sort of home we want to make of the Earth and the ways that geographical studies direct our attention to the forces and capacities that might help or hinder making such a home (Anon, 2010; Kearns, 2009).

Dowler and Hannah are correct to point to the separations and hierarchies that masculinist rhetoric polices within Geography. It is almost trite to remind students and colleagues that every time commentators contrast hard and soft science, they make precisely this sort of separation and privileging. The work that is needed to understand the ways that what Dowler terms the 'everyday manifestations of militarization' are related to 'geopolitical inquiry' is challenging and will build upon such exemplary studies as Puar's analysis of 'South Park and the Pakistani Leather Bottom' (Puar, 2007: 67-76). Puar's work challenges the reality of the separation between spheres and articulates a queer ethic that can cultivate resistance to the blandishments of male heterosexual privilege. Dowler suggests that one of the important ways the separate spheres are articulated is through the presentation of war as the protection of the domestic. With a Defense Department that organizes war this may seem self-evident but, again, it is very challenging to understand the instability of the separation between the domestic and the foreign and the chauvinistic injustice of privileging the first over the second. From immigration to public health to economic stability, the task of critical human geography is in part to show that borders are so porous that managing vulnerability can never be about relying upon fences. The very separation that allowed the identification of a discrete field of Geopolitics is thoroughly problematic. As Dowler suggests, part of the way that Geopolitics serves imperialism is by naturalizing these separations and hierarchies.

\section{References}

Agnew, J. (2003). Geopolitics: Re-visioning world politics (2nd ed.). New York: Routledge.
Agnew, J., \& Corbridge, S. (1995). Mastering space: Hegemony, territory and international political economy. London: Routledge.

Anon. (2010). Annual general meeting and medal and awards celebration. Geographical Journal, 176(3), 256-266.

Berdoulay, V. (1981). The contextual approach. In D. R. Stoddart (Ed.), Geography, ideology and social concern (pp. 8-16). Oxford: Blackwell

Blouet, B. W. (1987). Halford Mackinder: A biography. College Station TX: Texas A\&M Press.

Briggs, J., \& Sharp, J. (2004). Indigenous knowledges and development: a postcolonial caution. Third World Quarterly, 25(4), 661-676.

Cowen, D., \& Gilbert, E. (Eds.). (2008). War, citizenship, territory. New York: Routledge.

Dean, M. (1994). Critical and effective histories. Foucault's methods and historical sociology. London: Routledge.

Dean, R. (2001). Imperial brotherhood: Gender and the making of Cold War foreign policy. Amherst: University of Massachusetts Press.

Dowler, L. (2002). Women on the frontlines: rethinking war narratives post 9/11. GeoJournal, 58, 159-165.

Dowler, L., \& Sharp, J. (2001). A feminist geopolitics? Space and Polity, 5(3), 165-176.

Edney, M. (1997). Mapping an empire: The geographical construction of British India, 1765-1843. Chicago IL: University of Chicago Press.

Enloe, C. H. (2007). Globalization and militarism: Feminists make the link. Lanham MD: Rowman \& Littlefield.

Featherstone, D. (2008). Resistance, space and political identities: The making of counter-global networks. Oxford: Wiley-Blackwell.

Fluri, J. (2009). Geopolitics of gender and violence 'from below'. Political Geography, 28(4), 259-265.

Gillette, K. C. (1910). World corporation. Boston MA: New England News Company.

GoGwilt, C. (1995). The invention of the West. Joseph Conrad and the double-mapping of Europe and empire. Stanford CA: Stanford University Press.

GoGwilt, C. (2000). The fiction of geopolitics. Afterimages of culture, from Wilkie Collins to Alfred Hitchcock. Stanford CA: Stanford University Press.

Hannah, M. (2000). Governmentality and the mastery of territory in nineteenthcentury America. Cambridge: Cambridge University Press.

Hitler, A. (1971 [1925]). Mein Kampf. Boston MA: Houghton Mifflin.

Hobson, J. A. (1938 [1902]). Imperialism: A study (3rd ed.). London: Allen \& Unwin.

Hugill, Peter J. (1993). World trade since 1431: Geography, technology, and capitalism. Baltimore, MD: The Johns Hopkins University Press.

Hugill, P. J., \& Bachman, V. (2005). The route to the techno-industrial worldeconomy and the transfer of German Organic Chemistry to America before, during, and immediately after World War One. Comparative Technology Transfer and Society, 3(2), 159-186.

Kaplan, R. D. (2010). The geography of Chinese power. Foreign Affairs, 89, 22-41.

Kearns, G. (1998). The virtuous circle of facts and values in the New Western History. Annals of the Association of American Geographers, 88, 377-409.

Kearns, G. (2007). The history of medical geography after Foucault. In S. Elden, \& J. Crampton (Eds.), Space, knowledge and power: Foucault and Geography (pp. 205222). Aldershot: Ashgate Press.

Kearns, G. (2008). Taking theory for a walk in Ireland. In E. Gagen, H. Lorimer, \& A. Vasudevan (Eds.), Practicing the archive: Reflections on methods and practice in historical geography (pp. 9-22). London: Historical Geography Research Group.

Kearns, G. (2009). Geopolitics and empire: The legacy of Halford Mackinder. New York: Oxford University Press.

Kearns, G. (2010). Geography, geopolitics, and empire. Transactions of the Institute of British Geographers, 35, 183-207.

Kearns, G. Echoes of Schmitt among the ideologists of the new American Empire. In S. Legg (Ed.), Spatiality, sovereignty and Carl Schmitt: Geographies of the Nomos. London: Routledge, in press.

Kropótkin, P. (1902). Mutual aid: A factor of evolution. Boston MA: Porter Sargent.

Kropótkin, P. (1968 [1913]). The conquest of bread. New York: Benjamin Blom.

Laliberte, N., Driscoll Derikson, K., \& Dowler, L. (2010). In R. A. Denemark (Ed.), The international studies Encyclopedia. Blackwell Publishing. Blackwell Reference Online. 23 August $2010<$ http://www.isacompendium.com/public/book? id=g9781444336597_9781444336597>.

Mackinder, H. J. (1919). Democratic ideals and reality: A study in the politics of reconstruction. London: Constable.

Morin, K. (2008). Charles P. Daly's gendered geography, 1860-1890. Annals of the Association of American Geographers, 98(4), 897-919.

Norton-Taylor, R. (2010). Straw privately warned Blair that Iraq invasion was legally dubious. The Guardian Online. 17.01.10. At http://www.guardian.co.uk/uk/2010/ jan/17/straw-blair-iraq-war-letter-chil Accessed 24.05.10.

Oslender, U. (2007). Spaces of terror and fear on Colombia's Pacific Coast: The armed black conflict and forced displacement amongst black communities. In D. Gregory, \& A. Pred (Eds.), Violent geographies: Fear, terror and political violence (pp. 111-132). London: Routledge.

Puar, J. K. (2007). Terrorist assemblages: Homonationalism in queer times. Durham NC: Duke University Press.

Riverbend. Baghdad burning. Available at http://riverbendblog.blogspot.com/ Accessed 27.04.10

Routledge, P., \& Cumbers, A. (2009). Global justice networks: Geographies of transnational solidarity. Manchester: Manchester University Press.

Roy, A. (2002). Come September. Available at http://www.zmag.org/content/print_ article.cfm?itemID2404\&sectionID=15 Accessed 01.03.04. 
Said, E. (1979). Orientalism. New York: Vintage.

Sharp, J. (2000). Condensing the Cold War: Reader's Digest and American identity. Minneapolis: University of Minnesota Press.

Smil, V. (2001). Enriching the earth: Fritz Haber, Carl Bosch, and the transformation of world food production. Cambridge MA: MIT Press.
Ward, M. (1995). Unmanageable revolutionaries: Women and Irish nationalism. London: Pluto Press.

Zischka, A. (1936). Wissenschaft bricht Monopole. Der Forscherkampf um neue Rohstoffe und neuen Lebensraum. [Science breaks monopoly: the search for new resources and living-spaces]. Leipzig: Wilhelm Goldmann Verlag. 